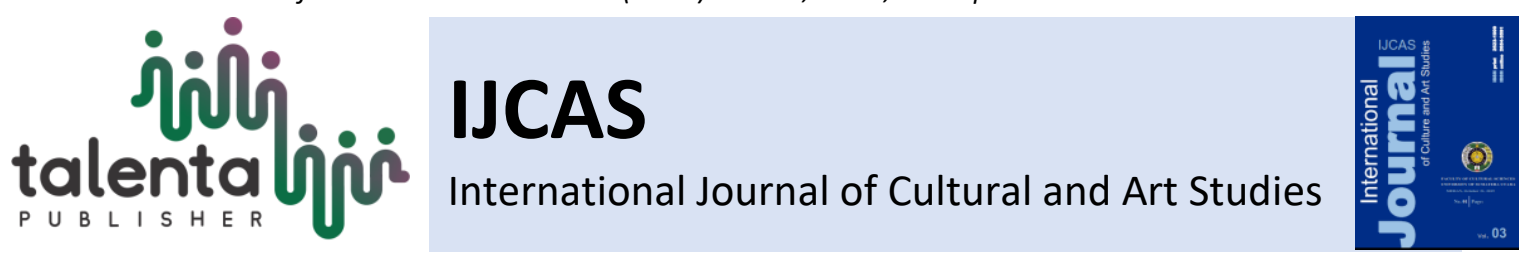

\title{
Neko 'Cat' in Japanese Idioms (Meaning and Figure of Speech Analysis)
}

\author{
Abdul Gapur ${ }^{1}$, Taulia ${ }^{2 *}$, Mhd. Pujiono ${ }^{3}$ \\ ${ }^{1,3}$ Faculty of Cultural Sciences, University of Sumatera Utara, Medan, Indonesia \\ ${ }^{2}$ Faculty of Communication and Languages, University of Harapan Medan, Indonesia
}

\begin{abstract}
Generally, idioms are formed with words related to the sense of taste, human body, color, numbers, growth, natural objects and animals. In this study, a Japanese idiom that is formed from neko 'cat' is discussed. This study is a qualitative research that aims to find out the lexical and idiomatical meaning of the idiom containing word neko and the figure of speech. The data are idioms with the word neko in 101 Japanese Idioms by Michael L. Maynard, and website (https://dictionary.goo.ne.jp). The results are that 13 idioms that use neko. Some idioms have a difference between lexical and idiomatic meaning. However, there is a link between the lexical and idiomatical meaning with the cultural and historical approach of the lexical used. Data contained in the 8 figure of speech Metaphor, namely neko mo shakushi mo (猫も构子も), neko ni koban (猫に小判), neko no hitai (猫の額), neko ni matatabi (猫にまたたび), neko in katsuobushi (猫に鰹節), neko no kubi ni suzu o tsukeru (猫の首に鈴を付ける), neko no ko ippiki inai (猫の子一 匹いない), neko o koroseba shichidai tataru（猫を殺せば七代崇る. Then 5 figure of speech are included in metonymy, namely neko no te mo karitai (猫の手も借りたい), neko o kaburu (猫をかぶる), karite kita neko (借りてきた猫), neko o ou yori sakana o noke yo (猫を追うより魚をのけよ), and neko o ou yori sara o hike (猫を追うより皿を 引け).
\end{abstract}

Keywords: Japaese Idiom, Neko, Figure of Speech

Received 20 October 2019| Revised 30 October 2019| Accepted 31 October 2019

\section{Introduction}

In linguistic terms, the form of the use of various languages related to expressions is manifested in various forms, one of which is an idiom. Idioms can be present when humans communicate with one another in daily activities, both oral and written. The problem for ordinary people is difficult to understand the meaning of idioms, because the explicit meaning in idioms is vague. Therefore, it must be connected to the actual meaning recognized and used by the language speakers concerned to communicate. [1, p. 25]

The word idiom comes from the Greek word idióma, which means 'specific property' or 'unique feature.' In Japanese, the idiom is called kanyouku (慣用句). From the meaning of the

\footnotetext{
* Corresponding author at: Faculty of Communication and Languages, University of Harapan Medan, Indonesia.
} 
letter, 慣 (kan, narau), means 'familiar, accustomed'; 用 (you, mochiiru), means 'utilize, business'; and 句 $(k u)$ means 'phrase, sentence.' Literally it can be said, kanyouku is a sentence or phrase that is used in accustomed, prevalent or common. [2, p. 4] Idioms are a variety of expressions that are widely used by people in everyday life and are 'most populous'. The point is, the formation of idioms is influenced by local wisdom which is the language characteristic of the community.[3, p. 62] Therefore, in two or more different countries, the word forming idioms can be interpreted differently, as the word 'cat' in this study.

The meaning of an idiom is a combination of the meaning of two or more words that have been set. The meaning cannot be digested based on the lexical meaning or the combined grammatical meaning of the background setting.[4, p. 12] Idioms are composed not in literal language, but in a metaphorical way. Metaphor makes the meaning of idioms different. Metaphor that in the old view is only a figurative language to beautify language. But in the current view is seen as an embodiment of the human mindset, which is a conceptualization, experience, both physical and mental, about the similarity between one thing and another. [5, p. 66]

Idioms in Japanese have several limitations, namely the arrangement of words that make up new pairs of words cannot be changed, it is not possible to add words or word inserts, and the meaning that appears only exists because of the combination of these words and the construction of their meanings is not the same as the combined meaning of words said the maker. [6, p. 38]

Japanese idioms are formed from various kinds of words, some are formed from parts of the human body, natural objects, colors, sense of taste, plant and animal. In this study, discussed idiom composed of animals, including cats 'neko' (猫). This study intends to explore the lexical and idiomatic meanings of Japanese idioms with the word 'neko' as a reflection of Japanese people's views regarding cats and the type of figure of speech contained therein.

On the other hand, Japanese learners rarely use the idiom. That could be caused by the lack of understanding of Japanese learners on idioms. The most common case in dokkai (reading) lessons is when Japanese learners interpret lexical idioms only. Whereas in translating the idiom is not all the words translated through its lexical meaning, because the lexical meaning is the actual meaning or the original meaning of the word. If learners do not understand idioms in their daily use in Japanese society, fluent communication will be difficult to realize. Therefore, this research can help provide an understanding of Japanese idioms and make it easier to understand various discourses in Japanese using idioms with the word neko.

\section{Methods}

This study is a qualitative. Moleong [7, p. 83] stated that qualitative research is research that intends to understand phenomena about what is experienced by the research subject, for 
example behavior, perception, motivation, action, etc. Holistically, and by way of description in the form of words and language, in a special natural context and by utilizing various natural methods.

The method used is descriptive method. Gay [8, p. 30] defines descriptive research as an activity which involves collecting data in order to test hypotheses or answer questions concerning circumstances at the time that are running from the subject of a study. Descriptive research determines and reports on the present situation.

The data sources in this study are book 101 Japanese Idioms by Michael L Maynard [9] and the website https://dictionary.goo.ne.jp/ that provides various data related to idioms with the word neko. The data are idioms that use the word neko.

In collecting data, the technique used is the note taking technique. The note taking technique according to Sudaryanto [10, p. 135] aims to record data obtained from observations. The data obtained is recorded on a data card or the record can use a computer. Then, in the study of the meaning of idiom, the writer will describe the phrase / clause and be analyzed from the lexical meaning, idiomatical meaning, and how the relationship between the two meanings in the idiom. The relation between lexical meaning (mojidouri no imi) and idiomatical meaning (kanyouteki na imi) is described. This is intended to explain why the idiomatic meaning emerged, from various perspectives, especially Japanese culture or customs. To clarify the relationship of meaning as used in cognitive linguistics as Sutedi [11, p. 209]used by using the three figure of speech, namely metaphor, metonymy, and synecdoche.

Metaphor (in-yu / 隠喻) is the style of language used to compare one thing (for example A) with another thing (for example B), because of the similarity. Metonymy ( $k a n-y u$ / 韓愈) is the style of language used to compare one thing (A) with another thing (B), because of the proximity or the existence of a connection both in space and in time. Synecdoche (teiyu / 提 喻) is the style of language used to equate something general (A) with something more specific (B), or vice versa thing (B) is likened to a general thing (A).

\section{Results and Discussion}

From the analysis of the data, the results were found that there were 13 idioms formed from the word neko. Next is the idiom table with the word neko.

Table 1. Idioms with the word neko

\begin{tabular}{|c|c|c|c|c|}
\hline \multirow[t]{2}{*}{ No } & \multirow[t]{2}{*}{ Idiom } & \multicolumn{2}{|c|}{ Meaning } & \multirow{2}{*}{$\begin{array}{c}\text { Figure of } \\
\text { Speech }\end{array}$} \\
\hline & & Lexical & Idiomatical & \\
\hline 1. & $\begin{array}{l}\text { 猫も杓子も } \\
\text { Neko mo shakushi mo }\end{array}$ & $\begin{array}{l}\text { Cat and bamboo } \\
\text { spoon }\end{array}$ & $\begin{array}{l}\text { Each person, } \\
\text { everyone }\end{array}$ & metaphor \\
\hline
\end{tabular}




\section{2. 猫に小判 \\ Neko ni koban}

3. 猫の額

Neko no hitai

4. 猫の手も借りたい

Neko no te mo karitai

5. 猫をかぶる

Neko o kaburu

6. 猫にまたたび

Neko ni matatabi

7. 借りてきた猫

Karite kita neko

8. 猫に鰹節

Neko ni katsuobushi

9. 猫の首に鈴を付ける

Neko no kubi ni suzu o tsukeru

10. 猫の子一匹いない Neko no ko ippiki inai

11. 猫を殺せば七代崇る

Neko o koroseba shichidai tataru

12. 猫を追うより魚をのけよ Neko o ou yori sakana o noke yo

13. 猫を追うより皿を引け Neko o ou yori sara o hike
Coins for cats

useless /

pointless

Cat's forehead

Very narrow

Want to borrow a Very busy

cat's hand

Cover the face

with a cat

Matatabi for cats

Borrowing cat

A piece of bonito

for cats

Put a bell on the cat's neck

There are no

kittens

If it kills a cat, it is condemned 7 generations

\section{Instead of} chasing a cat, it's better to take the fish

\section{Instead of} chasing a cat, just pull the dish cause of the problem
Lies, falsehoods,

Attention

Shy, quiet

Circumstances must not be careless

A good plan must be executed well

No one (person)

metaphor

bad luck

metaphor

Resolve the cause of the problem

Resolve the metonymy metonymy

\section{Karite kita neko（借りてきた猫）}

This idiom is formed from the neko noun「猫」 and the verb 'kariru' (借りる) means 'to borrow.' The verb 'kariru' belongs to the group of verbs II in Japanese, then after the verb is changed to the form $\sim \tau$, then the form $\sim \tau<る$ is followed. The $\sim$ た form in karite kita neko is the past form.

$\sim$ te kuru $\lceil\sim \tau<る 」$ on this idom means there is a change. Therefore, lexically can be interpreted as "borrowed cat." If the cat is taken to a place that is still unfamiliar to him, there will be a change in attitude from the cat, which is becoming more quiet and shy. This is because cats are not yet familiar with their new environment. Like the nature of the cat, this idiom describes someone who changes his character to be quiet and shy if not at home or in his own 
environment. This idiom uses the style of metonymy, which shows the relationship between the condition of a borrowing cat and the shame and quietness of someone.

An example of using this idiom in a conversation:

雅紀くんはお祖母さんの家に行くのが初めてだったので、借りてきた猫のよう だった。

Misaki-kun wa obaasan no ie ni ikuno ga hajimetedatta node, karitekita neko no you datta.

Because Masaki was the first time visiting Grandma's house, she seemed like a quiet person.

\section{Neko mo shakushi mo (猫も杓子も)}

This idiom is formed from the neko noun 「猫」, shakushi「杓子」 and particle mo「も」. The mo particle in this idiom serves to explain the same thing, which can be interpreted 'and, also'. Sakushi means rice spoon made of bamboo. Lexically, this idiom means 'cat and bamboo spoon.'

An example of using this idiom in a conversation::

A女：最近またスカート丈が少し短くなったようね。

Saikin mata sukaatotake ga sukoshikunatta you ne.

It looks like the skirt length has become a little shorter recently.

B女：そうなのよ。これで猫も杓子もみじかいスカートになるんでしょ。個 性がなくていやになるわね。まったく。

Sounano yo. Korede take neko mo shakushi mo mijikai sukaato ni narundesho. Kosei ga nakute iya ni naru wa ne. Mattaku.

You are right. Nowadays everyone also wears a short skirt. It's not your style at all, I don't like it. Really.

From the conversation above it can be understood that this idiom is used to express something that is actually not good and appropriate in society but has been done by many people. Therefore, this idiom is more appropriate if interpreted 'everyone'.

\section{Neko ni Koban（猫に小判）}

In this idiom, there is the noun koban (小 判). Koban is a small oval shaped gold coin that circulated in Japan before the Meiji restoration in 1868. Then the $n i 「 に 」$ particle showed the object to (for/to ). The $n i 「 に 」$ particle in this idiom is showing the given object. Therefore, this idiom means 'gold coin for cats.' 
When a cat if given a gold coin. Then the cat will not be interested in the coin because for cats the coin is not a useful object. Because of that, neko ni koban means something that is useless or pointless. This idiom uses a metaphorical style of language that shows the similarity or similarity between the state of 'a cat that is given a coin' with 'useless.'

An example of using this idiom in a conversation:

そんな小さな子にコンピュータ買い与えるなんて、猫に小判だ。

Sonna chisana ko ni konpyuuta kaiataeru nante, neko ni koban da.

It is useless to buy a computer for such a small child.

\section{Neko no hitai (猫の額)}

The idiom 'neko no hitai' is an idiom formed from two nouns, namely neko and hitai 「額」. Hitai means forehead. Then the particle 'no' in this idiom serves to explain that the word in front of the particle, namely hitai 「額」 is part of the previous word, which is neko 「猫」. Lexically this idiom means cat forehead.'

Cats are animals that do not have wide foreheads. So it idiomatically means narrow or not wide. This idiom uses a metaphorical style of language that shows the similarity or similarity between a cat's forehead with a narrow.

An example of using this idiom in a conversation::

A女：新しい庭付きの家に移ったんですって?

Atarashii niwatsuki no ie ni utsuttan desutte?

I heard you moved to a house with a yard?

B 男： いやね、庭といえるかどうか、ほんの猫の額のような裏庭がついてる 程度なんだ。

Iya ne, niwa to ieruka douka, hon no neko no hitai no you na ura niwa ga tsuiteru teido nan da.

Not really, what can be said by the yard or not, the condition is like a cat's forehead (not wide).

\section{Neko no te mo karitai (猫の手も借りたい)}

This idiom is formed from the noun neko and te「手」 which means hand. Particles no and mo as well as the verb 'kariru' which means to borrow. This verb undergoes a morphological process into a form of hope (kibou) by adding tai ( たい) at the end of the word to karitai 「借りたい」. 
Particle no $「 の\rfloor$ in this idiom serves as an explanation of ownership or part of something. Therefore, neko no te 「猫の手」 means cat's hand. The mo「も」 particle functions to explain doing something that has been done before by someone else. Can be interpreted either 'or also'

Lexically this idiom means 'want to borrow a cat's hand too.' This idiom shows the meaning of 'very busy', because everyday cats are always busy using their feet and hands to indulge. This idiom uses the style of metonymy, which shows the relationship between a cat's hand with the help of another person.

Example:

$$
\begin{aligned}
& \text { あの、ちょっとごめんなさい。ここの事務所、今日、引つ越しで、猫の手も借り } \\
& \text { たいような忙しさなの。あとで電話するよ。 }
\end{aligned}
$$

Ano, chotto gomennasai. Koko no jimusho, kyou, hikkoshi de, neko no te mo karitai youna isogashisanano. Atode denwa suru yo.

Sorry, because this office is moving we are very busy. I'll call later.

\section{Neko o kaburu (猫をかぶる)}

This idiom 'neko o kaburu' has the verb 'Kaburu' 「被る」, which means to wear something on the head. Kaburu can also be interpreted as 'cover.' Then there is the particle $o\lceil を 」$, which functions to show the object. Therefore, this idiom is interpreted as 'covering the cat face.' This is interpreted as something that is 'pretend innocence' and 'to play the hypocrite.'

Example:

\footnotetext{
無理を承知で頼むのだから、何を言われても猫をかぶって紳士でとおせ。 Muri wo shouchi de tanomu no dakara, nani wo iwaretemo neko wo kabutte shinshi de toose.

Since you ask with a notice that unreasonable, whatever you say, pretend innocence and be gentleman.
}

\section{Neko ni matatabi (猫にまたたび)}

This idiom is formed from the noun 'neko' and matatabi「またたび」. Matatabi is catnip. This plant is liked by cats because it can be used to cure diseases in cats. This idiom lexically means 'catnip for cats.' It idiomatically means 'attention' or 'pleasure.'

Example:

猫にまたたび、うちの子供にはテレビゲーム。 
Neko ni matatabi, uchi no kodomo ni terebigeemu.

My child loves television Games like catnip for cats.

\section{Neko ni katsuobushi (猫に鰹節)}

The lexical meaning of this idiom is 'a piece of bonito for cats,' and its idiomatic meaning is something that should not be careless.

Example:

食いしん坊と豪華な料理を家に残すなんて、猫に鰹節だ

Kuishinbō to gōkana ryōri o ie ni nokosu nante, Eko ni katsuobushi da.

Leaving glutton and gorgeous food at Home must not be careless.

The idiom above uses a metaphorical style that shows similarity. In a lexical meaning, 'a piece of bonito (fish) for a cat' has something in common with the state of not being careless. The word 'piece of fish for a cat' can reflect as a dangerous situation if left unchecked, like when we give a piece of fish to a cat, the cat will surely devour the fish right away. Therefore, we must not be careless about something that has the potential to endanger or harm us.

\section{Neko no kubi ni suzu o tsukeru (猫の首に鈴を付ける)}

The lexical meaning is 'putting a bell around the cat's neck', and its idiomatic meaning is something that is well planned and must be executed properly. The idiom above is based on the allegory of the group of mice that are discussing in dealing with cats. The results of the discussion of the mice agreed to put a bell on the neck of the cat to be a danger marker for mice when the cat comes. However, no one dared to put a bell on the cat's neck. This idiom explains that many things are easy to talk about but difficult at the execution stage. This idiom shows using a metaphorical style of language that shows similarity or similarity, where in a lexical meaning 'putting a bell on a cat's neck' has similarities to the condition that no one dares.

\section{Neko on Go ippiki inai (猫の子一匹いない)}

The lexical meaning of this idiom is 'even a kitten, does not exist' and the idiomatic meaning 'there is no person /no one.'

\section{Example:}

休暇中、少し自然の空気を吸いたい思い車を走らせ山間部に来たが、猫の小一匹いな いほど閑散としている。

Kyūka-chū, sukoshi shizen no kūki o suitai omoi-sha o hashira se sankan-bu ni kitaga, neko no ko ichi-biki inai hodo kansanto shite iru. 
During the holidays, I drove a car that wanted to breathe a little natural air and came to the mountains, but it was so quiet that nobody was.

The idiom above uses a metaphorical style that shows similarities. In lexical meaning 'kitten that does not exist' has similarities to the state of "there is no person."

\section{Neko o koroseba shichi dai tataru（猫を殺せば七代崇る）}

The lexical meaning of this idiom is 'if killing a cat, it will be condemned 7 generations' and its idiomatic meaning 'evil deeds will have a bad effect on the future.' The idiom above uses a metaphorical style of language that shows similarity or similarity, where the lexical meaning 'killing cats' has similarities to being cursed. This idiom is related to Japanese folklore, which tells us that cats are magical animals.

\section{Neko o ou yori sakana o noke yo and Neko o ou yori sara o hike}

\section{(猫を追うより魚をのけよ,および猫を追うより皿を引け)}

The lexical meaning of these two idioms is the same idiomatically, meaning that solving the root cause of the problem is better than solving the problem. Lexically is 'Neko o ou yori sakana o noke yo' means 'rather than Chase the cat, Way The fish,' and 'Neko o ou yori sara o hike' means ' Pull the dish than chasing a cat'.

This idiom uses the style of metonymy, which shows the relationship between fish and plates by attracting cat food. The lexical meaning 'taking fish \& pulling plates' is similar to idiomatically the meaning of 'root of the problem'.

\section{Conclusion}

There are 13 idioms that have the word ' $n e k o$ ' in Japanese.9 idioms are metaphors and 4 idioms are metonymy. No synecdoche idioms were found in the data. From the results of the analysis of the meaning of idioms with the word neko there are different idioms between lexical and idiomatic meanings. However, there is a link between lexical meaning and idiomatic meaning. The idiomatic meaning is formed from the lexical and cultural aspects and history of Japanese society.

\section{REFERENCES}

[1] A. Widiyani, "Makna Kanyouku yang Berkaitan Dengan Bagian Tubuh Hana (Hidung), Kuchi (Mulut), Mimi (Telinga), Me (Mata), Dan Shita (Lidah)," J. SORA, vol. 1, no. 1, pp. 25-38, 2016.

[2] A. Gapur, “Idiom Bahasa Jepang yang Berasal dari Kata Kucing 「猫」からできた日 本語の慣用句,” Universitas Sumatera Utara, 2013.

[3] D. W. Yogyanti, "Idiom 'Saru' Sebagai Refleksi Konsep Pemikiran Masyarakat Jepang Terhadap Monyet," Izumi, vol. 7, no. 2, p. 61, 2018. 
[4] F. Felicia, "Analisis Makna Kanyouku yang Menggunakan Kanji Koshi dalam Kodansha's Dictionary of Basic Japanese Idioms," Ling. Cult., vol. 7, no. 1, p. 11, 2016.

[5] A. Saifudin, "Konseptualisasi Citra Hara 'Perut' dalam Idiom Bahasa Jepang," Japanese Res. Linguist. Lit. Cult., vol. 1, no. 1, pp. 65-78, 2018.

[6] F. Ita, "Semantic Analysis on Japanese Idiom which Lexem Hand," IZUMI, vol. 3, no. 2, p. 38, Jul. 2014.

[7] M. Pujiono, "Pengurangan Bentuk Campur Kode Bahasa Jepang," Genta Bahtera, vol. 3, no. 1, pp. 81-89, 2017.

[8] A. P. Sari, "Analisis Makna Kanyouku (Idiom) Bahasa Jepang Yang Menggunakan Kata Iki (Napas)," Universitas Pendidikan Indonesia, 2016.

[9] M. L. Maynard and S. K. Maynard, 101 Japanese Idioms. Illinois: NTC Publishing, 1994.

[10] Sudaryanto, Metode dan Teknik Analisis Bahasa. Yogyakarta: Duta Wacana University, 2015.

[11] D. Sutedi, Dasar-Dasar Linguistik Bahasa Jepang. Bandung: Humaniora Utama Press, 2011. 